\title{
Pengaruh Penggunaan Metode Problem Solving Model Polya Terhadap Hasil Belajar Soal Cerita di Sekolah Dasar
}

\author{
Aprien Rahma Putri ${ }^{1)}$, Masniladevi ${ }^{2)}$, Desyandri ${ }^{3)}$ \\ ${ }^{1)}$ Mahasiswa, Universitas Negeri Padang, Indonsesia \\ ${ }^{2)}$ Pembimbing 1, Universitas Negeri Padang, Indonesia \\ ${ }^{3)}$ Pembimbing 2, Universitas Negeri Padang, Indonesia
}

Email: ${ }^{1)}$ aprienrahmaputri@ gmail.com, ${ }^{2)}$ masnila.devi@yahoo.co.id,

${ }^{3)}$ desyandri@fip.unp.ac.id

\begin{abstract}
Abstrak
Pelitian ini bertujuan untuk mengetahui pengaruh penggunaan metode problem solving model Polya terhadap hasil belajar soal ceritabangun datar siswa kelas V SD Gugus 1 Pariaman Utara. Jenis penelitian ini adalah eksperimen berbentuk Quasi Experimental Type Nonequivalent Control Group Design. Teknik pengambilan sampel menggunakan teknik simple random sampling dengan hasil dari beberapa pertimbangan. Instrumen yang digunakan berupa tes yaitu tes uraian. Teknik analisis data dalam penelitian ini menggunakan uji prasyarat berupa uji normalitas dan homogenitas serta uji hipotesis menggunakan uji-t. Hasil penelitian menunjukkan bahwa ada pengaruh yang signifikan dalam penggunaan metode problem solving model polya terhadap hasil belajar soal cerita luas bangundatar kelas V SD Gugus 1 Pariaman Utara. Hal ini dibuktikan dari hasil uji-t dengan taraf signifikansi 5\% diperoleh thitung $=3,71>$ ttabel $=1,72$. Hasil belajar matematika yang diperoleh kelompok eksperimen lebih tinggi dari pada kelompok kontrol, ditunjukkan dari mean kelompok kontrol= 73,09 dan mean yang diperoleh kelompok eksperimen $=87,18$.
\end{abstract}

Kata Kunci: metode problem solving model polya

\section{The Effect of Using Problem Solving Method with Polya Model to Students Learning Outcome About Narrative Story In Elementary School}

\begin{abstract}
This research aims to determine the effect of using the problem solving method of the Polya model on learning outcomes about the story of the flat-waking class V students of Elementary School 1 North Pariaman. This type of research is Quasi Experimental Type Nonequivalent Control Group Design. The sampling technique used simple random sampling technique with the results of several considerations. The instrument used is a test that is a description test. Data analysis techniques in this study used a prerequisite test in the form of normality and homogeneity tests and hypothesis testing using the t-test. The results showed that there was a significant influence in the use of the problem solving model method on the learning outcomes of the story about the flat-building area of class V SD Cluster 1 North Pariaman. This is evidenced by the results of the $t$-test with a significance level of 5\% obtained $t_{\text {count }}=3.71>t_{\text {table }}=1.72$. Mathematics learning outcomes obtained by the experimental group were higher than in the control group, indicated by the control group mean $=73.09$ and the mean obtained by the experimental group $=87.18$.
\end{abstract}

Keywords: method of problem solving, model of polya

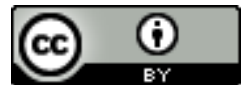




\section{PENDAHULUAN}

Education is a conscious and planned effort in an ethical, systematic and creative way in which learners develop self potential, intelligence, self-control and skills to make themselves useful in society (Lenny Zaroha; Firman; Desyandri, 2018). Pendidikan di sekolah dasar bermaksud untuk memberikan bekal kemampuan dasar kepada siswa berupa pengetahuan, keterampilan, dan sikap yang bermanfaat bagi diri mereka sendiri sesuai dengan tingkat perkembangannya, serta mempersiapkan mereka untuk mampu melanjutkan ke jenjang pendidikan sekolah menengah pertama (Arlis, 2013: 113). Sehingga sangat diharapkan para pendidik mampu menyajikan pembelajaran dengan metode pembelajaran yang sesuai dengan materi ajar agar siswa dapat dipersiapkan secara matang. Di samping itu, guru terkesan masih menggunakan paradigma pembelajaran konvensional, terutama metode ceramah (Desyandri, 2012). Peserta didik tidak diberikan kesempatan untuk memecahkan masalah yang berkaitan dengan pembelajarannya (Alfianiawati, Desyandri, \& Nasrul, 2019).

Dimana metode pembelajaran dapat diartikan sebaga titik tolak atau sudut pandang kita terhadap proses pembelajaran, yang merujuk pada pandangan tentang terjadinya suatu proses pada duni pendidikan termasuk pendidikan di sekolah dasar. Metode yang dipilih haruslah sesuai dengan materi pelajaran
Available on: http://ejournal.unp.ac.id/students/index.php/pgsd yang akan di sampaikan, karena dengan pemilihan metode yang tepat akan membantu siswa dan guru dalam melaksanakan pembelajaran. Salah satu metode yang cocok digunakan dalam pembelajaran matematika untuk penyelesaian sola cerita luas bangun datar layang-layang dan trapesium adalah metode problem solving (pemecahan masalah) model polya. Hal ini Sejalan dengan pendapat Suwangsih dan Tiurlina (2006: 126) bahwa pemecahan masalah adalah "proses penerimaan tantangan untuk menyelesaikan suatu masalah dengan terurut".

Metode problem solving merupakan salah satu cara untuk memecahkan permasalahan berdasarkan masalah yang terjadi dalam kehidupan sehari-hari sehingga siswa dihadapkan pada suatu permasalahan nyata agar siswa mampu menyelesaikan permasalahan tersebut dengan individual maupun kelompok. Hal ini sejalan dengan pendapat Taufik dan Muhammadi (2012: 167) keunggulan metode problem solving ini adalah: a) melatih siswa untuk merencanakan dalam melakukan penemuan, b) mengajak siswa untuk berpikir dan bertindak kreatif, c) memecahkan masalah yang dihadapi siswa berdasarkan kehidupan nyata, mengidentifikasi masalah yang dihadapi siswa, e) melakukan dan mengevaluasi hasil yang ditemukan siswa berdasarkan permasalah yang dihadapi, f) merangsang siswa untuk menyelesaikan masalah yang dihadapi dengan 
tepat, dan g) membuat pendidikan sekolah lebih relevan dengan kehidupan nyata siswa.

Dalam pelaksanaan atau penerapan metode problem solving model polya haruslah menerapkan empat langkah-langkah pemecahan masalah, sejalan dengan pendapat Sheikh, dkk (2015: 7-8) langkah-langkah pemecahan masalah adalah "1) Understand the problem (memahami masalah), 2) Devising a plan (membuat rencana penyelesaian), 3) Carrying out the plan(melaksanakan rencana), 4) Looking back (memeriksa kembali)".

Dengan menerapkan metode problem solving polya dapat membuat siswa aktif, kritis, kreatif, dan mendorong siswa untuk melalkukan evaluasi sendiri terhadap hasil maupun proses belajarnya. Sehingga nantinya hasil belajar siswa akan mengalami perubahan kearah yang lebih baik. Hal ini sejalan dengan pendapat Sanjaya (2008: 220) adalah : 1) merupakan teknik yang cukup bagus untuk memahami isi pembelajaran. 2) dapat menantang kemampuan siswa serta memberi kepuasan untuk menemukan pengetahuan baru lagi bagi siswa. 3) dapat meningkatkan aktifitas pembelajaran siswa, 4) dapat membantu siswa bagaimana mentransfer pengetahuan mereka untuk memahami masalah dalam kehidupan nyata, 5) dapat membantu siswa mengembangkan pengetahuan barunya dan bertanggung jawab dalam pembelajaran yang mereka lakukan, disamping itu problem solving juga dapat mendorog untuk melakukan evaluasi sendiri baik terhadap hasil maupun proses belajarnya, 6) bisa memperlihatkan kepada siswa hanya setiap mata pelajaran, bahwa pada dasarnya merupakan cara berfikir dan sesuatu yang harus dimengerti oleh siswa, bukan hanya sekedar belajar dari guru atau buku-buku saja, 7) dianggap lebih menyenangkan dan disukai siswa, 8) dapat mengembangkan kemampuan siswa untuk berfikir kritis dan mengembangkan kemampuan mereka untuk menyesuaikan dengan pengetahuan baru, 9) dapat memberikan kesempatan pada siswa mengaplikasikan pengetahuan yang mereka miliki dalam dunia nyata, 10) dapat mengembangkan minat siswa untuk secara menerus belajar pada pendidikan formal telah berakhir.

Berdasarkan keterangan di atas, metode problem solving model polya sangat cocok digunakan dalam pembelajaran matematika untuuk penyelesaian soal cerita. Karena matematika merupakan ilmu pengetahuan yang aplikasinya sangat mempengaruhi perkembangan ilmu pengetahuan dan teknologi karena matematika dapat membentuk seseorang meempunyai daya nalar yang tinggi dalam pemecahan masalah dan mampu menjabarkan secara logis dan sistematis.

Karena tujuan pembelajaran matematika adalah untuk melatih siswa bertindak atas dasar pemikiran secara logis, kritis, cermat, jujur, efektif, dan efisien. Siswa diharapkan dapat menggunakan matematika serta pola 
pikirnya dalam kehidupan sehari-hari, karena pada kenyataannya ilmu Matematika tidak dapat dipisahkan dari kehidupan sehari-hari. Hal ini sejalan dengan pendapat Depdiknas (2006: 417) “1) memahami konsep Matematika 2) menggunakan penalaran pada pola dan sifat 3) memecahkan masalah 4) mengkomunikasikan gagasan dengan simbol, tabel, diagram, atau media lain 5) memiliki rasa ingin tahu, perhatian, dan minat dalam mempelajari matematika serta sikap ulet dan percaya diri dalam pemecahan masalah.”

Salah satu materi matematika yang dipelajari di Sekolah Dasar kelas V semester I sesuai dengan KTSP adalah menyelesaikan masalah yang berkaitan dengan luas bangun datar trapesium dan layang-layang. Siswa diharapkan dapat memahami cara menyelesaikan masalah yang berkaitan dengan soal cerita luas bangun datar sebagaimana yang terdapat dalam Kurikulum Tingkat Satuan Pendidikan (KTSP) yang dikemukakan Depdiknas (2006: 8) "Standar Kompetensi: 3. Menghitung luas bangun datar sederhana dan menggunakannya dalam pemecahan masalah. Kompetensi Dasar: 3.2 Menyelesaikan masalah yang berkaitan dengan luas bangun datar.

Pembelajaran menyelesaikan masalah soal cerita yang berkaitan dengan luas bangun datar trapesium dan layang-layang ini siswa tidak akan mengalami kesulitan dalam mengaplikasikannya di kehidupan nyata apabila dengan menggunakan langkah-langkah
Available on: http://ejournal.unp.ac.id/students/index.php/pgsd penyelesaian yang terurut. Oleh sebab itu pembelajaran mengenai materi menyelesaikan masalah penyeesaian soal cerita tentang luas bangun datar ini sangat cocok diajarkan dengan menggunakan metode problem solving model polya, karena menurut Adjie dan Maulana (2007: 7) bahwa "pemecahan masalah merupakan proses penerimaan tantangan dan kerja keras untuk menyelesaikan masalah tersebut".

Sebagai pedoman untuk perbandingan hasil belajar yang akan diteliti, peneliti melakukan observasi di SDN Gugus I Kecamatan Pariaman Utara pada pada tanggal 2 April, 9 April dan 2-3 Juli di kelas V Sekolah Dasar Gugus 1 Pariaman Utara, peneliti menemukan bahwa latar belakang permasalahan yang dihadapi siswa di lapangan adalah ketika proses pembelajaran berlangsung sebagian besar siswa hanya diam dalam pembelajaran karena disaat siswa diberikan latihan dalam bentuk soal cerita, guru tidak mengarahkan langkah-langkah sesuai dengan tahapan menyelesaikan masalah dalam bentuk soal cerita. Guru tidak membimbing siswa dalam merencanakan penyelesaian masalah sehingga siswa mengalami kesulitan dalam menyelesaikan soal tersebut dengan baik.

Selain itu, sejalan dengan pandangan yang mengemukakan bahwa guru dan siswa mengalami beberapa permasalahan, yaitu: 
pembelajaran masih berpusat pada guru, kurangnya kesempatan siswa memperoleh pengalaman langsung baik mengamati, menanya, mencobakan, mengolah informasi, dan mengkomunikasikan (Desyandri \& Vernanda, 2017).

Fakta lainnya ketika melihat siswa dalam menyelesaikan soal cerita yang diberikan oleh guru, jawaban yang ditulis benar namun dalam langkah pengerjaannya belum bertahap. Karena siswa kurang memahami masalah yang diinformasikan pada soal cerita sehingga membuat siswa keliru dalam mengumpulkan informasi soal yang diketahui, ditanya dan siswa juga masih ada yang belum menyelesaikan soal dengan langkah-langkah yang terurut sehingga berdampak pada hasil belajar siswa matematika siswa.

Di Gugus I Kecamatan Pariaman Utara cenderung menerapkan pembelajaran yang bersifat konvensional yaitu guru menjelaskan materi dengan metode ceramah, dalam pembelajaran siswa juga kurang terbiasa menyelesaikan soal cerita dengan langkah bertahap yang menyebabkan kurangya interaksi dan kerjasama dalam proses pembelajaran. Hal tersebut berdampak pada rendahnya hasil belajar siswa kelas V Gugus I SD Kecamatan Pariaman Utara.

Berdasarkan uraian diatas, maka peneliti ingin mengetahui "Pengaruh Penggunaan Metode Problem Solving Model Polya Terhadap Hasil Belajar Soal Cerita
Available on: http://ejournal.unp.ac.id/students/index.php/pgsd

Luas Bangun Datar Kelas V SD Gugus 1

Pariaman Utara".

\section{METODE PENELITIAN}

Penelitian ini merupakan jenis penelitian kuantitatif dimana menurut Masniladevi (2017: 89) penelitian dengan pendekatan kuantitatif ini merupakan penelitian dengan menggunakan angka-angka dalam mendeskripsikan subjek penelitian. Sedangkan desain yang digunakan dalam penelitian ini adalah nonequivalent control group design. Dalam penelitian ini, teknik pengambilan sampel dilakukan dengan carapurposive Sampling.

Tabel 1. Rancangan Desain Penelitian Nonequivalent Control Group Design

\begin{tabular}{cccc}
\hline Kelompok & Pre-test & Perlakuan & Post-test \\
\hline Eksperimen & $\mathrm{O}_{1}$ & $\mathrm{X}$ & $\mathrm{O}_{2}$ \\
Kontrol & $\mathrm{O}_{3}$ & - & $\mathrm{O}_{4}$ \\
\hline
\end{tabular}

(Sugiyono, 2012: 116)

Keterangan :

$\mathrm{X}$ : Penggunaan metode problem solving model Polya

$\mathrm{O}_{1}$ : Pre-test (hasil belajar siswa sebelum menggunakan metode problem solving model Polya)

$\mathrm{O}_{2}$ : Post-test (hasil belajar siswa sesudah menggunakan metode problem solving model Polya)

$\mathrm{O}_{3}$ : Pre-test (hasil belajar siswa sebelum menggunakan model pembelajaran konvensional)

$\mathrm{O}_{4}$ : Post-test (hasil belajar siswa menggunakan model pembelajaran konvensional).

Populasi dalam penelitian ini adalah seluruh kelas V Gugus 1 Kecamatan Pariaman Utara. Teknik pengambilan sampel adalah



This work is licensed under a Creative Commons Attribution 4.0 International License 
simple random sampling. Maka dari 11 sekolah yang dijadikan populasi, peneliti hanya memilih sampel berdasarkan kriteria yang telah dipilih oleh peneliti. Sampel tersebut diambil karena beberapa alasan, yaitu 1) sekolah yang menggunakan KTSP 2006, 2) kedua kelas memiliki jumlah siswa yang sama. Berdasarkan kriteria yang telah ditentukan oleh peneliti maka terpilihlah 3 SD yang memakai KTSP. Lalu diantara ketiga sekolah tersebut dilakukan uji prasyarat terhadap siswa kelas V SDN 13 Tungkal Selatan, SDN 19 Cubadak Air Utara dan SDN 20 Sintuk sehingga didapat hasil bahwa ketiga kelas tersebut berdistribusi nomal dan homogen.

Setelah sampel ditentukan sampel dengan teknik simple random sampling, kemudian dilakukan pengundian untuk menentukan kelompok eksperimen dan kelompok kontrol. Sehinnga diperoleh sampel di dalam penelitian ini adalah siswa kelas $\mathrm{V}$ SDN 13 Tungkal Selatandan SDN 19 Cubadak Air Utarayang masing-masing kelas berjumlah 11 orang. Setelah melakukan pengundian sederhana maka terpilihlah SDN 13 Tungkal
Available on: http://ejournal.unp.ac.id/students/index.php/pgsd Selatan sebagai kelas eksperimen dan SDN 19 Cubadak Air Utara sebagai kelas kontrol. Jadi sampel penelitian ini adalah SDN 13 Tungkal Selatan, SDN 19 Cubadak Air Utara pada semester ganjil tahun pelajaran 2018/ 2019.

Penelitian ini menggunakan intrumen tes. Dimana instrumen adalah salah satu hal penting ada dalam proses penelitian. Sejalan dengan pendapat Sugiyono (dalam Desyandri, dkk 2018: 28) menyatakan bahwa "instrumen penelitian adalah suatu alat yang digunakan untuk mengukur fenomena alam maupun sosial yang diamati. Dalam hal ini, fenomena yang disebutkan yaitu variabel penelitian”.

Instrumen yang akan digunakan dalam penelitian ini adalah berupa tes soal uraian dengan menggunakan pedoman pemberian skor pemecahan masalah. Butir-butir soal tes dibuat berdasarkan indikator pembelajaran yang berjumlah 10 butir soal uraian, kemudian diuji cobakan dan dilakukan uji validitas, reabilitas, uji beda, dan taraf kesukaran untuk mendapatkan soal yang baik yang bisa digunakan untuk pelaksanaan penelitian.

Tabel 2. Pedoman Pemberian Skor Pemecahan Masalah

\begin{tabular}{|c|c|c|c|c|}
\hline Skor & $\begin{array}{l}\text { Mema hami } \\
\text { Masa lah }\end{array}$ & $\begin{array}{l}\text { Membuat Rencana } \\
\text { Pemecahan } \\
\text { Masalah }\end{array}$ & $\begin{array}{l}\text { Melaku kan } \\
\text { Perhitu ngan }\end{array}$ & $\begin{array}{c}\text { Memeriksa } \\
\text { Kembali Hasil }\end{array}$ \\
\hline$\overline{0}$ & $\begin{array}{l}\text { Salah } \\
\text { Menginterpretasikan/ salah } \\
\text { sama sekali. }\end{array}$ & $\begin{array}{l}\text { Tidak ada rencana, membuat } \\
\text { rencana yang tidak relevan. }\end{array}$ & $\begin{array}{l}\text { Tidak } \\
\text { perhitungan. }\end{array}$ & $\begin{array}{l}\text { Tidak ada pemeriksaan atau tidak } \\
\text { ada keterangan lain. }\end{array}$ \\
\hline 1 & $\begin{array}{l}\text { Salah } \\
\text { Menginterpre-tasikan } \\
\text { sebagian soal/mengabai- } \\
\text { kan soal. }\end{array}$ & $\begin{array}{l}\text { Membuat rencana } \\
\text { yang tidak dapat } \\
\text { diselesaikan. }\end{array}$ & $\begin{array}{l}\text { Melakukan prosedur yang } \\
\text { benar dan mungkin } \\
\text { menghasilkan } \\
\text { jawaban benar tetapi salah } \\
\text { perhitungan. }\end{array}$ & $\begin{array}{l}\text { Ada pemeriksaan } \\
\text { tetapi tidak tuntas. }\end{array}$ \\
\hline 2 & $\begin{array}{l}\text { Memahami } \\
\text { masalah soal } \\
\text { selengkapnya. }\end{array}$ & $\begin{array}{l}\text { Membuat rencana } \\
\text { yang benar tetapi } \\
\text { salah dalam hasil, }\end{array}$ & $\begin{array}{l}\text { Melakukan proses yang } \\
\text { benar dan mendapatkan hasil } \\
\text { yang benar. }\end{array}$ & $\begin{array}{l}\text { Pemeriksaan } \\
\text { dilaksanakan untuk } \\
\text { kebenaran }\end{array}$ \\
\hline
\end{tabular}

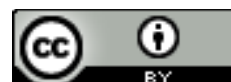

This work is licensed under a Creative Commons Attribution 4.0 International License 


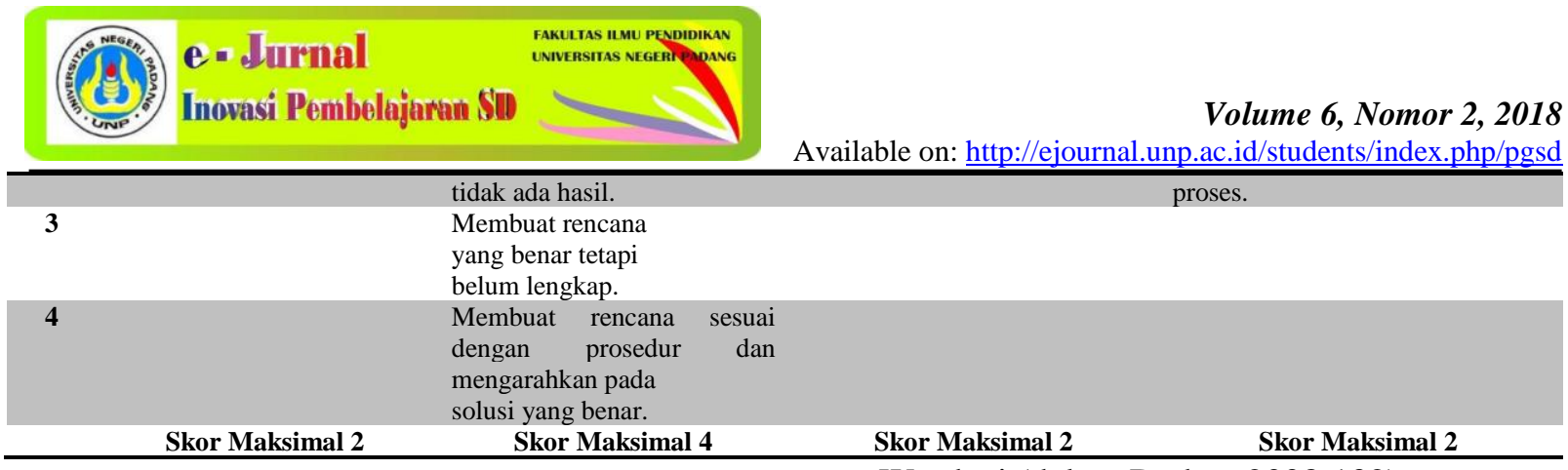

Wardani (dalam Dadan, 2008:132)

\section{HASIL DAN PEMBAHASAN}

\section{Deskripsi Data Pretest Kelas Eksperimen dan Kelas Kontrol}

Nilai pretest kedua kelompok, baik itu kelompok eksperimen dan kelompok kontrol, di dapat dari jawaban soal pretest siswa sebelum diberikan perlakuan. Pretest dilakukan dengan tujuan untuk mengukur pengetahuan awal siswa mengenai pelajaran matematika pada materi menyelesaikan masalah yan berkaitan dengan luas bangun datar. Perhitungan hasil pretest kelompok eksperimen dan kelompok kontrol dapat tabel hasil pretest sebagai berikut:

Tabel 3. Nilai Pretest Kelompok Kontrol dan Kelompok Eksperimen

\begin{tabular}{|c|c|c|c|c|}
\hline \multirow{2}{*}{$\begin{array}{l}\text { Nilai } \\
(x)\end{array}$} & \multicolumn{2}{|c|}{$\begin{array}{c}\text { Kelompok } \\
\text { Kontrol }\end{array}$} & \multicolumn{2}{|c|}{$\begin{array}{c}\text { Kelompok } \\
\text { Eksperimen }\end{array}$} \\
\hline & $(f)$ & $x . f$ & $(f))$ & $x . f$ \\
\hline 0 & 3 & 0 & 3 & 0 \\
\hline 1 & & & 1 & 1 \\
\hline 2 & 3 & 6 & 1 & 2 \\
\hline 3 & & & 2 & 6 \\
\hline 4 & 3 & 12 & 1 & 4 \\
\hline 5 & & & 1 & 5 \\
\hline 6 & & & 1 & 6 \\
\hline 7 & & & 1 & 7 \\
\hline 8 & 1 & 8 & & \\
\hline 9 & 1 & 9 & & \\
\hline 10 & & & & \\
\hline$\sum$ & 11 & 35 & 11 & 31 \\
\hline
\end{tabular}

Dari penjelasan tersebut dapat disimpulkan bahwa semua siswa memperoleh nilai dibawah nilai minimal pembelajaran matematika. Maka terlihatlah bahwa antara kelompok kontrol dan kelompok eksperimen memiliki nilai yang hampir sama. Dimana semua siswa yang masing-masing 11 orang kelompok kontrol dan 11 orang kelompok eksperimen memperoleh nilai dibawah nilai minimum atau dibawah KKM pembelajaran matematika.

Adapun data statistik pre-test mengenai kedua kelompok berdasarkan perhitungan statistik dapat memudahkan peneliti dalam perhitungan uji prasyarat dan uji hipotesis nantinya. Data statistik pretest mengenai kedua kelompok berdasarkan perhitungan, sebagai berikut:

Tabel 4. Data Statistik Nilai Pre-test Kelompok Kontrol dan Kelompok Eksperimen

\begin{tabular}{ccc} 
& \multicolumn{2}{c}{ Pre-test } \\
\cline { 2 - 3 } Data Statistik & Kelompok & Kelompok \\
& Kontrol & Eksperimen \\
\hline Nilai Terendah & 0 & 0 \\
\hline Nilai Tertinggi & 9 & 7 \\
\hline Mean & 3.18 & 2.81 \\
\hline Modus & 0 & 0 \\
\hline Median & 2 & 3
\end{tabular}




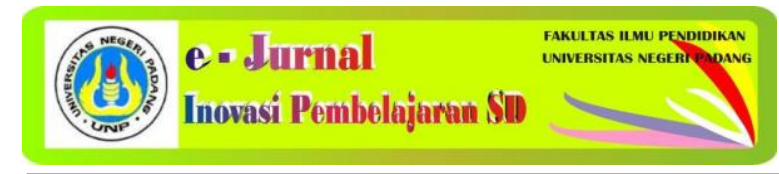

\begin{tabular}{ccc}
\hline Varian & 9.36 & 6.16 \\
\hline Simpangan Baku & 3.06 & 2.48 \\
\hline Jumlah Siswa & $\mathbf{1 1}$ & $\mathbf{1 1}$
\end{tabular}

Berdasarkan tabel di atasdapat diketahui bahwa nilaiuntuk kedua kelompok masih tergolong rendah atau dapat dikatakan masih dibawah KKM pembelajaran matematika.

\section{Deskripsi Data Posttest Kelas Eksperimen dan Kelas Kontrol}

Nilai posttest kedua kelompok, baik itu kelompok eksperimen dan kelompok kontrol, didapat dari jawaban soal posttest siswa sesudah diberikan perlakuan. Posttest dilakukan dengan tujuan untuk mengukur pengetahuan siswa sesudah mendapatkan perlakuan mengenai pelajaran matematika pada materi menyelesaikan masalah yan berkaitan dengan luas bangun datar. Perhitungan hasil posttest kelompok eksperimen dan kelompok kontrol dapat dilihat pada tabel hasil posttest kelompok eksperimen dan kelompok kontrol adalah sebagai berikut:

Tabel 5. Rangkuman Nilai Post-test Kelompok Kontrol dan Kelompok Eksperimen

\begin{tabular}{ccccc}
\hline & \multicolumn{2}{c}{ Kelompok Kontrol } & \multicolumn{2}{c}{ Kelompok Eksperimen } \\
\cline { 2 - 5 } Nilai & $(\boldsymbol{f})$ & $\boldsymbol{x} \boldsymbol{f}$ & $(\boldsymbol{f}))$ & $\boldsymbol{x} \cdot \boldsymbol{f}$ \\
$(x)$ & & & & \\
$\mathbf{5 7}$ & 1 & 57 & & \\
$\mathbf{5 9}$ & 1 & 59 & & 70 \\
$\mathbf{7 0}$ & 1 & 70 & 1 & \\
$\mathbf{7 3}$ & 1 & 73 & & 75 \\
$\mathbf{7 4}$ & 1 & 74 & & 1 \\
$\mathbf{7 5}$ & & & & \\
\hline
\end{tabular}

Volume 6, Nomor 2, 2018 Available on: http://ejournal.unp.ac.id/students/index.php/pgsd

\begin{tabular}{ccccc}
\hline $\mathbf{7 6}$ & 1 & 76 & 1 & 76 \\
$\mathbf{7 7}$ & 1 & 77 & & \\
$\mathbf{7 9}$ & 2 & 158 & & \\
$\mathbf{8 0}$ & 2 & 160 & & 85 \\
$\mathbf{8 5}$ & & & 1 & 87 \\
$\mathbf{8 7}$ & & & 1 & 90 \\
$\mathbf{9 0}$ & & & 1 & 91 \\
$\mathbf{9 1}$ & & & 1 & 288 \\
$\mathbf{9 6}$ & & & 3 & 97 \\
$\mathbf{9 7}$ & & & 1 & $\mathbf{9 5 9}$ \\
\hline$\sum$ & $\mathbf{1 1}$ & $\mathbf{8 0 4}$ & $\mathbf{1 1}$ & \\
\hline
\end{tabular}

Dari tabel di atas, terlihatlah bahwa perolehan nilai posttest kelompok kontrol dapat disimpulkan bahwa nilai 9 siswa dari kelompok kontrol telah memperoleh nilai di atas minimal pembelajaran matematika.

Sedangkan perolehan nilai posttest kelompok eksperimen dapat disimpulkan bahwa nilai 11 orang siswa dari kelompok eksperimen telah memperoleh nilai di atas minimal pembelajaran matematika.

Dari penjelasan diatas, terlihatlah bahwa kelompok kontrol dan kelompok eksperimen memiliki peningkatan nilai setelah dilakukan pembelajaran dengan model pembelajaran yang berbeda.

Jika dilihat banyaknya peningkatan banyak siswa yang telah memperoleh nilai di atas nilai minimum pembelajaran matematika setelah dilakukan dengan model yang berbeda, maka pembelajaran dengan menggunakan metode problem solving model polya yang mengalami peningkatan yang pesat.

Adapun data statistik posttes mengenai kedua kelompok berdasarkan perhitungan adalah sebagai berikut: 

yang diperoleh terdistribusi normal dan

Tabel 6. Data Statistik Nilai Post-test Kelompok Kontrol dan Kelompok Eksperimen

\begin{tabular}{ccc}
\multirow{2}{*}{ Data Statistik } & \multicolumn{2}{c}{ Post-test } \\
\cline { 2 - 3 } & $\begin{array}{c}\text { Kelompok } \\
\text { Kontrol }\end{array}$ & $\begin{array}{c}\text { Kelompok } \\
\text { Eksperimen }\end{array}$ \\
\hline Nilai Terendah & 57 & 70 \\
\hline Nilai Tertinggi & 80 & 97 \\
\hline Mean & 73.09 & 87.18 \\
\hline Modus & 79 & 96 \\
\hline Median & 74 & 90 \\
\hline Varian & 65.69 & 92.56 \\
\hline Simpangan Baku & 8.1 & 9.62 \\
\hline Jumlah Siswa & 11 & 11
\end{tabular}

Berdasarkan tabel di atas, menunjukkan hasil posttest untuk kedua kelompok. Terlihat bahwa nilai terendah yang diperoleh kelompok kontrol sebesar 57 sedangkan pada kelompok eksperimen sebesar 70 dan nilai tertinggi yang diperoleh kelompok kontrol sebesar 80 sedangkan pada kelompok eksperimen sebesar 97.

Selain itu terlihat pula nilai rata-rata (mean) yang diperoleh kelompok kontrol sebesar 73.09 sedangkan nilai rata-rata (mean) kelompok eksperimen sebesar 87.18. Selisih nilai rata-rata (mean) kedua kelompok adalah sebesar 14,09.

\section{Pengujian Persyaratan Analisis dan Pengujian Hipotesis}

Setelah data hasil penelitian di dapatkan, maka data akan diolah melalui uji hipotesis. Sebelum melakukan uji hipotesis, terlebih dahulu dilakukan pengujian prasyarat analisis data, yaitu uji normalitas dan homogenitas guna mengetahui apakah data mempunyai ragam yang homogen atau tidak. Adapun hasil yang di dapat setelah dilakukan pengujian prasyarat analisis data adalah sebagai berikut:

\section{Uji Normalitas}

Uji normalitas digunakan untuk mengetahui apakah data yang diperoleh dari masing-masing kelas/kelompok sampel berdistribusi normal atau tidak.Pengujian ini dilakukan dengan menggunakan uji liliefors. Dari pengujian diperoleh Lo (L Litung ) dan $\mathrm{Lt}$ $\left(\mathrm{L}_{\text {tabel}}\right)$ untuk kedua sampel pada taraf nyata $(\alpha$ $=0.05)$.

Berikut ini rangkuman hasil uji normalitas dari hasil belajar siswa pada kelompok kontrol dan kelompok eksperimen.

Tabel 7. Rangkuman Hasil Uji Normalitas

\begin{tabular}{llcccc} 
& Data & N & Lo & Lt & KET \\
\hline \multirow{2}{*}{ Pre-test } & Eksperimen & 11 & 0,144 & 0,249 & Normal \\
\cline { 2 - 6 } & Kontrol & 11 & 0,212 & 0,249 & Normal \\
\hline \multirow{2}{*}{ Post-test } & Eksperimen & 11 & 0,153 & 0,249 & Normal \\
\cline { 2 - 6 } & Kontrol & 11 & 0,196 & 0,249 & Normal
\end{tabular}

Dari pengujian normalitas pretest pada kelas eksperimen dan kelas kontrol diperoleh nilai kelas eksperimen dengan $\mathrm{L}_{\text {hitung }}=0,144$ dengan $\mathrm{L}_{\text {tabel }}=0,249$ dan nilai kelas kontol dengan $\mathrm{L}_{\text {hitung }}=0,212$ dengan $\mathrm{L}_{\text {tabel }}=0,249$ pada taraf signifikan 0,05 . Sedangkan pada pengujian normalitas posttest pada kelas ekperimen diperoleh nilai $\mathrm{L}_{\text {hitung }}=0,153$ dengan $\mathrm{L}_{\text {tabel }}=0,249$ dan pada kelas kontrol

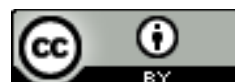

This work is licensed under a Creative Commons Attribution 4.0 International License 
diperoleh nilai $\mathrm{L}_{\text {hitung }}=0,196$ dengan $\mathrm{L}_{\text {tabel }}=$ 0,249 pada taraf signifikan 0,05.

Berdasarkan tabel di atas, kedua sampel tersebut sama-sama menunjukan $\mathrm{L}_{\mathrm{hitung}}$ lebih kecil dari $\mathrm{L}_{\text {tabel, }}$ maka sampel hasil pretest dan posttest kelompok eksperimen dan kelompok kontroldinyatakan normal.

\section{Uji Homogenitas}

Uji homogenitas pada penelitian ini dengan menggunakan uji Harley, dengan kriteria uji homogenitas yang digunakan adalah jika $F_{\text {hitung }}$ lebih kecil dari $F_{\text {tabel}}$, maka data tersebut berdistribusi homogen, jika $F_{\text {hitung }}$ lebih besar dari $\mathrm{F}_{\text {tabel }}$ maka data tersebut tidak berdistribusi homogen.

Hasil uji homogenitas kedua kelompok sampel pada penelitian yang telah dilaksanakan dapat dilihat seperti pada tabel di bawah ini.

Tabel 8. Rangkuman Hasil Uji Homogenitas

\begin{tabular}{|c|c|c|c|c|}
\hline \multirow{2}{*}{$\begin{array}{c}\text { Data } \\
\text { Statistik }\end{array}$} & \multicolumn{2}{|c|}{ Pretest } & \multicolumn{2}{|c|}{ Posttest } \\
\hline & $\begin{array}{c}\text { Eksperi- } \\
\text { men }\end{array}$ & Kontrol & $\begin{array}{c}\text { Eksperi- } \\
\text { men }\end{array}$ & Kontrol \\
\hline Varian & 6.16 & 9.36 & 92.56 & 65.69 \\
\hline $\begin{array}{c}\text { Varian } \\
\text { Terbesar }\end{array}$ & \multicolumn{2}{|c|}{9.36} & \multicolumn{2}{|c|}{92.56} \\
\hline $\begin{array}{c}\text { Varian } \\
\text { Terkecil }\end{array}$ & \multicolumn{2}{|c|}{6.16} & \multicolumn{2}{|c|}{65.69} \\
\hline$F_{\text {hitung }}$ & \multicolumn{2}{|c|}{1,52} & \multicolumn{2}{|c|}{1,41} \\
\hline $\mathrm{F}_{\text {tabel }}$ & \multicolumn{2}{|c|}{3.28} & \multicolumn{2}{|c|}{3.28} \\
\hline Simpulan & Hor & gen & $\mathrm{Hol}$ & gen \\
\hline
\end{tabular}

Dari pengujian homogenitas pretest pada kelas eksperimen diperoleh nilai $F_{\text {hitung }}=$ 1,52 dengan $\mathrm{F}_{\text {tabel }}=3.28$ pada taraf signifikan 0,05. Sedangkan pada pengujian homogenitas posttest pada kelas ekperimen dan kelas
Available on: http://ejournal.unp.ac.id/students/index.php/pgsd kontrol diperoleh nilai $F_{\text {hitung }}=1,41$ dengan $F_{\text {tabel }}=3,28$ pada taraf signifikan 0,05 .

Berdasarkan tabel di atas, kedua sampel tersebut sama-sama menunjukan $\mathrm{F}_{\text {hitung }}$ lebih kecil dari $\mathrm{F}_{\text {tabel, }}$ maka sampel hasil pretest dan posttest kelompok eksperimen dan kelompok kontrol dinyatakan homogen.

\section{Uji Hipotesis}

Uji prasyarat analisis data normalitas dan homogenitas menyatakan bahwa kedua sampel dalam keadaan normal dan homogen, sehingga perhitungan analisis data dapat dilakukan dengan menggunakan rumus uji t, pada taraf signifikasi 5\% dan " $\mathrm{df} / \mathrm{db}=\mathrm{n}+\mathrm{n} 2-2$ " dengan kriteria yaitu ( $\mathrm{t}_{\text {hitung }}>\mathrm{t}_{\text {tabel }}=\mathrm{H}_{\mathrm{a}}$ diterima) dan ( $\mathrm{t}_{\text {hitung }}<\mathrm{t}_{\text {tabel }}=\mathrm{H}_{\mathrm{a}}$ ditolak).

Uji hipotesis dilakukan terhadap nilai posttest kelas eksperimen dan kelas kontrol. Berdasarkan uji prasyarat analisis data, diketahui bahwa data posttest untuk kedua kelompok berdistribusi normal dan memiliki varian yang homogen. Sehingga dapat dilakukan pengujian hipotesis dengan menggunakan uji-t.

Hasil perhitungan nilai posttest dengan menggunakan uji $\mathrm{t}$ disajikan pada tabel halaman berikut:

Tabel 9. Uji Hipotesis Hasil dengan Uji T

\begin{tabular}{ccc} 
Keterangan & \multicolumn{2}{c}{ Post-test } \\
\hline Kelas & Eksperimen & Kontrol \\
\hline $\mathrm{N}$ & 11 & 11 \\
\hline Rata-rata & 87.18 & 73.09 \\
\hline $\mathrm{T}_{\text {hitung }}$ & 3.71 \\
\hline $\mathrm{T}_{\text {tabel }}$ & 1.72 \\
\hline Kesimpulan & Terdapat perbedaan pengaruh
\end{tabular}




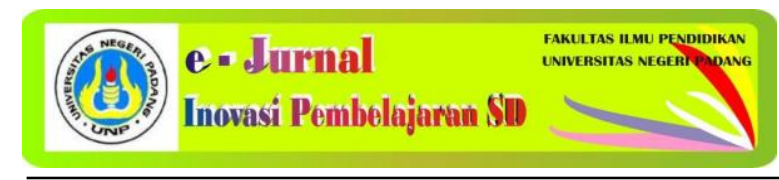

Berdasarkan tabel di atas diperoleh nilai pada hasil posttest $\mathrm{t}_{\text {hitung }}=3.71 \mathrm{dan} \mathrm{t}_{\text {tabel }}=$ 1.72 dengan taraf signifikasi 0.05 danderajat kebebasan $(d f / d b=11+11-2=20)$. Ini menunjukan bahwa $t_{\text {hitung }}>t_{\text {tabel }}$ atau3.71 $>1.72$ dengan demikian maka $\mathrm{H}_{0}$ ditolak dan $\mathrm{H}_{\mathrm{a}}$ diterima dan dinyatakan terdapat perbedan kelas eksperimen dengan kelas kontrol terhadap hasil belajar siswa. Hal ini dikarenakan siswa telah mendapatkan perlakuan yang berbeda sehingga terdapat perbedaan antara rata-rata nilai posttest kelas eksperimen dan kelas kontrol.

Pada uji hipotesis tampak bahwa pada nilai kedua kelompok setelah diberi perlakuan berbeda menghasilkan $t_{\text {hitung }}>t_{\text {tabel }}(3.71>1.72)$ sehingga hipotesis $\mathrm{H}_{0}$ ditolak, $\mathrm{H}_{\mathrm{a}}$ diterima. Hal tersebut menunjukan rata-rata hasil belajar matematika siswa kelas eksperimen lebih baik dari pada rata-rata hasil belajar matematika kelas kontrol.

Maka dapat disimpulkan bahwa terdapat pengaruh hasil belajar matematika yang signifikan antara siswa yang mendapat perlakuan dengan metode problem solving model polya dengan siswa yang mendapat pembelajaran dengan model pembelajaran biasa (konvensional). Perbedaan hasil belajar tersebut bukan terjadi secara kebetulan, akan tetapi karena perbedaan metode pembelajaran yang digunakan terbukti memberikan pengaruh yang berbeda secara signifikan terhadap hasil belajar matematika.
Volume 6, Nomor 2, 2018 Available on: http://ejournal.unp.ac.id/students/index.php/pgsd Sehingga pada pembahasan, penelitian ini dilakukan untuk mengetahui pengaruh dalam penggunaan metode problem solving model polya terhadap hasil belajar matematika siswa kelas V SD di Gugus 1 kecamatan Pariaman Utara tahun ajaran 2018/2019. Penelitian dilaksanakan pada 7 Agustus - 21 Agustus sebanyak dua kali pertemuan pada masing-masing kelas sampel (eksperimen dan kontrol), standar kompetensi, kompetensi dasar serta materi yang sama.

Dalam pelaksanaan, sebelum dilakukan pembelajaran untuk kedua kelas, terlebih dahulu diberikan pretest. Pretest bertujuan untuk melihat kondisi awal kedua kelompok (kesetaraan antara kelompok kontrol dan kelompok eksperimen) dan sebagai dasar perubahan hasil belajar. Pretest dilaksanakan dengan menggunakan 10 soal uraian yang terlebih dahulu telah diujicobakan dan dianalisis validitas soal, reabilitas soal, indeks kesukaran, dan daya bedanya.

Setelah diberikan pretest pada kedua kelas, maka dilakukanlah pembelajaran dengan metode problem solving model polya pada kelas eksperimen dan pembelajaran dengan model konvensional pada kelas kontrol.

Setelah dilakukan pembelajaran untuk kedua kelompok, maka selanjutnya diberikan posttest.Posttest disini bertujuan untuk melihat sejauh mana hasil belajar siswa setelah dilakukan dua model pembelajaran yang berbeda untuk kedua kelas.Kemudian, dilakukan uji prasyarat analisis yakni uji

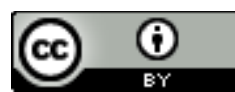

This work is licensed under a Creative Commons Attribution 4.0 International License 
normalitas dan homogenitas data.Tujuan dari uji normalitas adalah untuk mengetahui apakah data berdistribusi normal atau tidak. Uji normalitas pada penelitian ini menggunakan uji liliefors dengan ketentuan $\mathrm{L}_{\text {hitung }}<\mathrm{L}_{\text {tabel }}$ maka data berdistribusi normal pada taraf signifikasi 0,05 . Selanjutnya dilakukan uji homogenitas dengan menggunakan uji harley yaitu varians terbesar dibanding varians terkecil, dengan kriteria $F_{\text {hitung }}<\mathrm{F}_{\text {tabel }}$ artinya data berasal dari data yang homogen. Berdasarkan hasil analisis data pretest dan posttest diperoleh bahwa hasil belajar kedua kelompok berdistribusi normal dan memiliki varian yang homogen. Hal ini menunjukkan bahwa kondisi awal kedua kelompok baik itu kelompok kontrol maupun kelompok eksperimen berasal dari kondisi yang sama.

Dari hasil uji hipotesis yang telah dilakukan menunjukkan bahwa penggunaan metode problem solving model polya ini berdampak positif terhadap hasil belajar siswa. Sesuai yang telah diungkapkan oleh Anitah (2008:5.32) keunggulan dari metode problem solving yaitu "1) mengembangkan kemampuan berfikir ilimiah, 2) mengembangkan kemampuan berfikir kritis, 3) mempelajari bahan pelajaran yang aktual dengan kebutuhan dan perkembangan masyarakat, 4) jika dilaksanakan secara kelompok dapat mengembangkan kemampuan sosial siswa, dan 5) mengoptimalkan kemampuan siswa".

Berdasarkan analisis diatas, telah terbukti bahwa terdapat pengaruh yang signifikan pada pembelajaran dengan metode problem solving model polyaterhadap hasil belajar matematika siswa kelas V SD di Gugus 1 Kecamatan Pariaman Utara. Pada kelas yang melakukan pembelajaran dengan metode problem solving model polya memiliki ratarata yang lebih tinggi dari pada menggunakan model konvensional, yaitu rata-rata kelas eksperimen 87,18 dan kelas kontrol 73,09. Hal ini disebabkan metode problem solving model polyalebih membuat siswa mampu berpikir kritis di dalam pembelajaran, meningkatkan pemahaman materi kepada siswa dan siswa diarahkan untuk belajar secara mandiri berdasarkan kemampuan yang dimiliki. Meskipun diberikan materi yang sama dengan waktu yang berbeda, namun pada pembelajaran dengan model konvensional nilai yang diperoleh siswa tidak semaksimal metode problem solving model polya.

Selanjutnya Astriningsih, dkk (2015) menjelaskan model pembelajaran polya merupakan model pembelajaran yang memusatkan pada keterampilan pemecahan masalah. Dalam pembelajaran siswa dihadapkan dalam masalah-masalah kehidupan nyata dan siswa dituntut untuk memecahkan masalah menggunakan langkah-langkah pemecahan masalah yang benar.

Walaupun demikian, terdapat beberapa perbedaan diantaranya pada penelitian terdahulu seperti tempat 
materi ajar.

\section{SIMPULAN}

Berdasarkan analisis data penelitian yang telah dilakukan, maka dapat disimpulkan bahwa metode problem solving model polyaberpengaruh terhadap hasil belajar matematika kelas V SD di Gugus 1 Kecamatan Pariaman Utara. Pengaruh ini dapat terlihat dari hasil uji t yang telah dilakukan, diperoleh $t_{\text {hitung }}$ sebesar 3.71 dan $t_{\text {tabel }}$ pada taraf kepercayaan $5 \%(\alpha=0.05)$ adalah sebesar 1,72. Sehingga $t_{\text {hitung }}>t_{\text {tabel }}(2,95>1,72)$ ini berarti hipotesis $\mathrm{H}_{\mathrm{a}}$ diterima dan $\mathrm{H}_{\mathrm{o}}$ ditolak dalam arti kata bahwa terdapat pengaruh yang signifikan antara hasil belajar matematika siswa kelompok eksperimen yang menggunakan model metode problem solving model polya dan kelompok kontrol menggunakan model konvensional. Dengan demikian dapat disimpulkan bahwa terdapat pengaruh yang signifikan penggunaan metode problem solving model polya terhadap hasil belajar matematika siswa kelas V SD di Gugus 1 Kecamatan Pariaman Utara.

\section{DAFTAR RUJUKAN}

Adjie, N dan Maulana. (2007). Pemecahan Masalah Matematika. Bandung: UPI PRESS.

Arikunto, S. (2010). Prosedur Penelitian Suatu Pendekatan Praktik. Jakarta: Rineka Cipta.

Arlis, Sy. (2013, November). Penerapan Pendekatan Kontekstual Dalam Pembelajaran Ipa Di Sekolah Dasar. Padang: UNP. Diambil pada 31 Oktober 2018 dari http://ejournal.unp.ac.id/index.php/ped agogi

Astriningsih, dkk. (2015). Penerapan Model Polya Berbantuan Soal Cerita untuk Meningkatkan Hasil Belajar Matematika Siswa Kelas V Semester I. eJournal PGSD Universitas Pendidikan Ganesha. Jurusan PGSD Vol:3 No: 1 Tahun: 2015.

Dadan Sundawan, Mohammad. (2008). Pengaruh Penggunaan Model Pembelajaran Konstruktivisme Terhadap Kemampuan Pemecahan Masalah Matematik Siswa. Cirebon: Universitas Swadaya Gunung Jati.

Depdiknas. (2006). Kurikulum Tingkat Satuan Pendidikan (KTSP). Jakarta: Badan Standar Nasional Pendidikan.

Alfianiawati, T., Desyandri, \& Nasrul. (2019). Pengaruh Penggunaan Model Problem Based Learning terhadap Hasil Belajar Siswa dalam Pembelajaran ISD di Kelas V SD. Ejournal Pembelajaran Inovasi: Jurnal Ilmiah Pendidikan Dasar, 7(3), 1-10. Retrieved from http://ejournal.unp.ac.id/students/index .php/pgsd/article/view/5400/2795 
Desyandri. (2012). The Usage of Contextual Teaching and Learning (CTL) Approach to improve the process and learning outcome of Singing to the Student Class III Elementary School YPKK of Padang State University. Pedagogi: Jurnal Ilmu Pendidikan, 12(1), 36-52. Retrieved from http://pedagogi.ppj.unp.ac.id/index.php /pedagogi/article/view/231

Desyandri, D., \& Vernanda. (2017). Pengembangan Bahan Ajar Tematik Terpadu di Kelas V Sekolah Dasar Menggunakan Identifikasi Masalah. In Seminar Nasional HDPGSDI Wilayah 4 (pp. 163-174).

Lenny Zaroha; Firman; Desyandri. (2018). The Effect of Using Quantum Teaching and Motivation in Learning Toward Students Achievement. JAIPTEKIN | Jurnal Aplikasi IPTEK Indonesia, 2(4), 14-20. https://doi.org/https://doi.org/10.24036 /4.32143

Desyandri, dkk. (2018). Pengaruh Penggunaan Pendekatan Keterampilan Proses Terhadap Hasil Belajar Materi Tumbuhan Hijau Di Kelas V. Padang: UNP. Diambil pada 31 Oktober 2018 dari

http://ejournal.unp.ac.id/students/index .php/pgsd.

Masniladevi. (2017, Desember). Jurnal Inovasi Pendidikan Dan Pembelajaran Sekolah Dasar. Padang: UNP. Diambil pada 31 Oktober 2018 dari http://ejournal.unp.ac.id/index.php/jippsd.

Sanjaya, W. (2008). Strategi Pembelajaran Berorientasi Standar Proses Pendidikan. Jakarta: Prenada Media Group.

Sheikh, dkk. (2015). Problem solving method: A method for Independent learning in
Mathematics. International Islamic University, Islamabad: Lecturer Department of Education. (online), (https://www.researchgate.net/publicati on/274713189_HOPE_JOURNAL_OF _RESEARCH_Problem_solving_meth od_A_method_for_Independent_learni ng_in_Mathematics_HOPE_JOURNA L_OF_RESEARCH)

Sugiyono. (2012). Metode Penelitian Pendidikan: Pendekatan Kuantitatif, Kualitatif, dan $R \& D$. Bandung: Alfabeta.

Suwangsih, E dan Tiurlina. (2006). Model Pembelajaran Matematika. Bandung: UPI Press.

Taufik, Taufina, dan Muhammadi. (2012). Mozaik Pembelajaran Inovatif. Padang: Sukabina Press. 